\title{
'Onze voetzorggroep is klein, de problematiek die we verhelpen groot'
}

Marianne Lensink, voorzitter stichting Loop

In het kader van ons jaarthema Podopost Samen voor Kwaliteit interviewden we Marianne Lensink. Zij is nu anderhalf jaar voorzitter van stichting Loop, de overkoepelende brancheorganisatie voor de voetkundig (sport)adviseur, registerpodoloog en podoposturaal therapeut. 'De voetzorg en beroepsgroepen die zich daarmee bezighouden zijn te weinig zichtbaar.'

Tekst Maureen Limpens, hoofdredacteur | Foto's Herbert Wiggerman

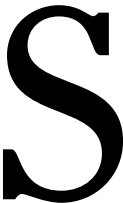

tichting Loop (Landelijk Overkoepelend Orgaan voor de Podologie) is in de pedicurebranche geen onbekende. Menig pedicure werkt samen met een registerpodoloog en er zijn ook meerdere vakgenoten die zelf een opleiding tot voetkundig adviseur (basisopleiding Podologie) of registerpodoloog hebben gevolgd. De brancheorganisatie maakt een vergelijkbare ontwikkeling door als ProVoet. 'Ook wij moeten inspelen op de vraag vanuit de zorgmarkt en duidelijkheid verschaffen naar verwijzers, patiënten en zorgverzekeraars over de kennis en kunde van onze leden', stelt Marianne Lensink. Ze studeerde verplegingswetenschappen en hbo-v. Ze was als verpleegkundige - en daarna als manager - achttien jaar werkzaam in het UMC Utrecht. Later was ze onder meer bestuurder van een ziekenhuis en directeur van Zorgverzekeraars Nederland. 'Het zichtbaar maken van voetzorgaanbieders en de kwaliteit van hun voetzorg is heel belangrijk.'

\section{Beroepscode}

Stichting Loop telt zo'n 500 leden en werkt op uiteenlopende manieren aan de kwaliteit van haar eigen achterban. Lensink somt op: 'Onze leden zijn verplicht om bij- en nascholing te volgen en om geregistreerd te blijven in het KABIZ-register. Een keer in de vijf jaar moeten ze een audit (HCA) ondergaan op inhoud en

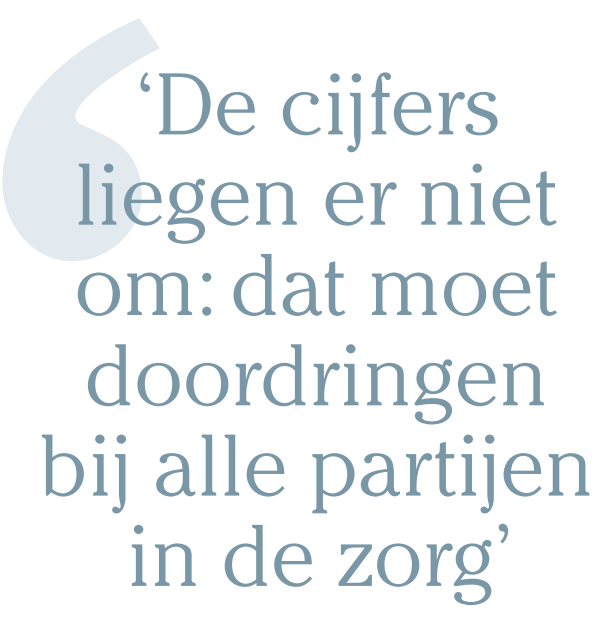

organisatie van hun praktijk. Er is een beroepscode waarin duidelijk staat wat er van de professional wordt verwacht. Daarnaast worden op regionaal niveau PRIO's gehouden (Podologen Regionaal Informatief Overleg, red.) voor kennisoverdracht en intervisie. We werken steeds meer samen in een multidisciplinaire setting. Ook staan we in nauw contact met de opleiding (Academie voor Podologie, red.) om te bekijken hoe we de kwaliteit kunnen versterken. Zo wordt bijvoorbeeld nu meer aandacht besteed aan echografie, dat een belangrijke meerwaarde biedt bij de diagnostiek. Tevens komt er aandacht voor de instrumentele voetbehandeling, zodat de registerpodoloog betrokken kan worden bij de diabetische voetzorg. En we meten nadrukkelijk de zogeheten Prem en Prom (Patient Reported Experience Measures en Patient Reported Outcome Measures, red.). Hieruit blijkt of een klacht is afgenomen en hoe de patiënt de kwaliteit van de zorg ervaart.' De patiënt vult de vragenlijst individueel in en de gegevens worden in een centrale database verzameld.

\section{Te weinig bekendheid}

'Aanbieders van voetzorg zijn maatschappelijk nog te weinig zichtbaar en voetzorg is nog te weinig bekend', vindt Lensink. 'Ik heb jarenlang als verpleegkundige in het ziekenhuis gewerkt en zag toen dat voetzorg meer aandacht verdient. Er zijn genoeg cijfers om het belang van voetzorg aan te tonen, maar die zijn niet algemeen bekend. Uit onderzoek komt naar voren dat 20 tot 30 procent van de patiënten bij de huisarts een aandoening aan het bewegingsapparaat heeft. Dat 8 procent voet- en enkelpijn heeft. Tegelijkertijd geeft 64 procent van de jonge huisartsen aan onvoldoende kennis te hebben van de voeten. Dit soort gegevens moeten we veel meer onder de aandacht brengen. Als voetproblemen chronisch worden en veel pijn veroorzaken, dan heeft dat ingrijpende consequenties voor patiënten. Dat kan zelfs zodanig zijn dat het hun participatie in de samenleving beperkt, waarbij we ook het mentale aspect van voetproblemen 
niet moeten onderschatten. En naar verwachting zullen aandoeningen aan de voeten de komende twintig jaar fors stijgen. Door reuma, diabetes, artrose of het ouder worden an sich. De groep mensen die daarmee te maken krijgt, zal in 2040 met respectievelijk 26, 25 en 41 procent zijn gegroeid. Het aantal 65 -plussers is tegen die tijd met 44 procent gestegen. Dat kan veel uitval opleveren.' 'In de gezondheidszorg is nu veel aandacht voor gezonde leefstijlinterventies, ook voor mensen met obesitas. Zij krijgen het advies om meer te gaan bewegen, maar door het overgewicht zijn hun knieën en voeten al overbelast. Dat neemt alleen maar toe als zij meer moeten bewegen. Dus ook daar kun je uitval verwachten. Daarom moet de voetzorg meer bekendheid krijgen.'

\section{Inzetten op preventie}

Met de focus op preventieve voetzorg kun je veel problemen voorkomen. 'Je moet standaard podologische zorg inzetten', vindt Lensink. Daarmee bedoelt ze dat er een jaarlijkse voetscreening in de basisverzekerde zorg opgenomen moet worden, zoals in het eerste interview in deze serie (Podopost nr. 1, 2021) ook al geopperd werd door ProVoet-voorzitter Ben Wagemakers. Podopost is benieuwd wie de screening dan volgens Marianne Lensink zou moeten uitvoeren. 'De registerpodoloog kan dat doen, maar ook andere partijen uit de voetzorg. We weten dat een preventieve voetscreening leidt tot minder complicaties, minder opnames en minder zorgkosten. Om weer enkele cijfers te noemen: je hebt dan 28 procent minder uitgaven aan pijnmedicatie en 36 procent minder kans op vallen. Voetproblemen verhogen de kans op vallen met 62 procent. Vandaar dat ik een jaarlijkse voetscreening van groot belang vind. Dus als je door preventie kunt zorgen dat minder mensen vallen en geen participatieproblemen
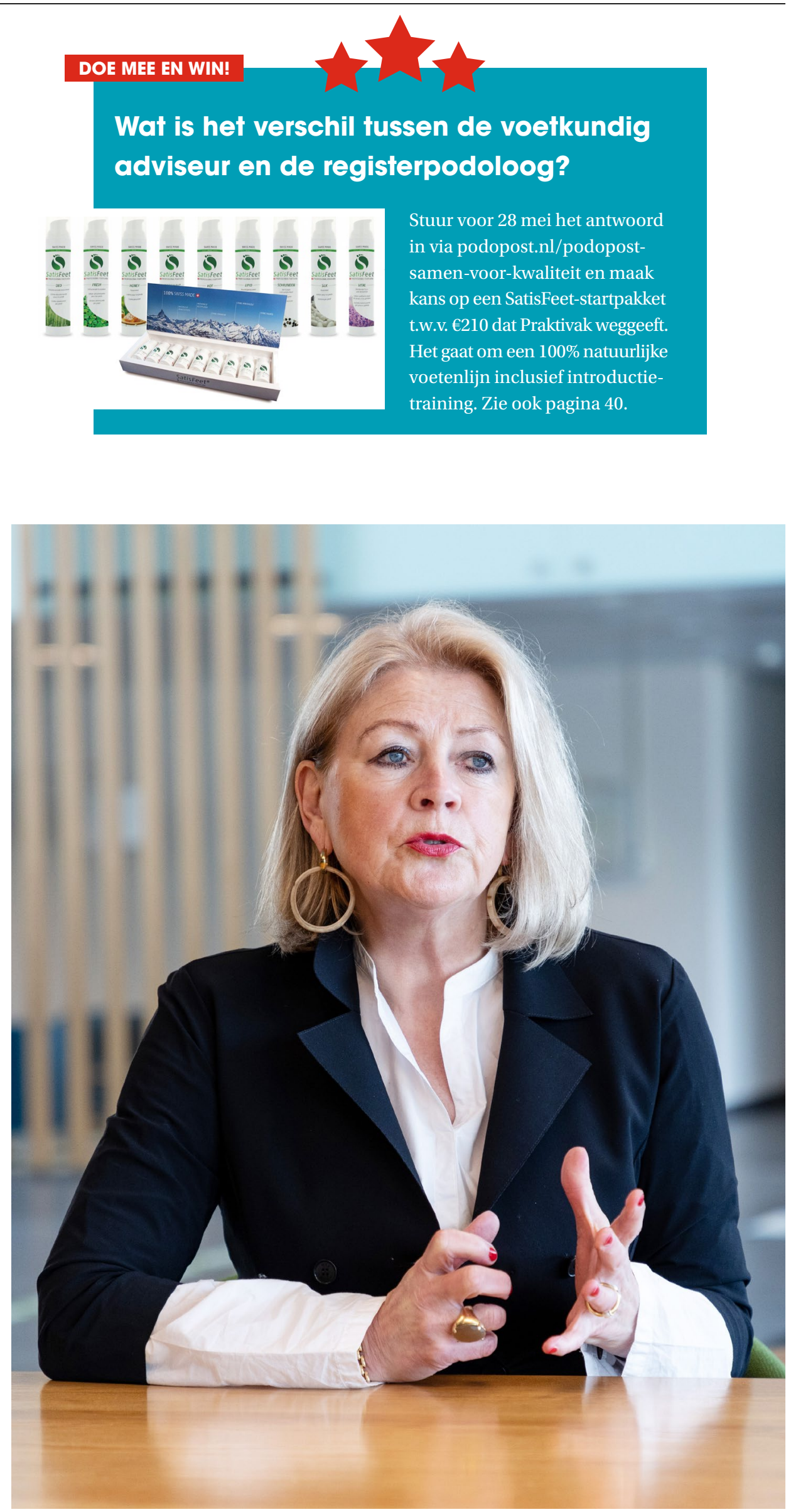

- 'Naar verwachting zullen aandoeningen aan de voeten de komende twintig jaar fors stijgen.' 
krijgen, dan bespaart dat ook weer de nodige kosten. De cijfers liegen er niet om. Dat moet gaan doordringen, bij alle partijen in de zorg.'

\section{Screening in basisverzekering}

'Zo'n preventieve voetscreening moet worden opgenomen in de basisverzekering. Het moet voor iedereen toegankelijk zijn', benadrukt de voorzitter die zelf regelmatig haar voeten door een pedicure en een registerpodoloog onder handen laat nemen.

'Daarnaast is het van belang dat alle voetzorgpartijen gezamenlijk inhoud geven aan het Kwaliteitskader Voetzorg. Dus wat kan de patiënt van ons verwachten op het gebied van kwaliteit. Ook voor de inkoop door zorgverzekeraars is dat van belang. We kunnen met behoud van overeenkomsten en verschillen tussen de voetzorgaanbieders voetzorg op inhoud met elkaar vormgeven.'

De COVID-19-pandemie heeft er overigens voor gezorgd dat er tussen de beroepsorganisaties van podologen, podotherapeuten, orthopedisch schoenmakers en pedicures meer onderling contact is ontstaan. 'De pandemie bracht de noodzaak voor goede voetzorg nog eens duidelijk voor het voetlicht.'

\section{Richtlijnen en onderzoek}

Een ander belangrijk punt volgens Lensink: voetzorg moet meer aandacht krijgen en landelijk moet er geld beschikbaar komen voor het ontwikkelen van richtlijnen voor deze zorg. 'Dan kun je ook laten zien hoe belangrijk die voetzorg is. Een masteropleiding zou ook bijdragen en we zullen veel meer op onderzoek moeten insteken. (Eveneens een punt dat terug te lezen is in het beleidsplan van ProVoet, red.). Een hoogleraar voor de voetzorg zou dat onderzoek kunnen aanjagen. Dat zag je ook in de verpleging. Toen er een Kwaliteitskader Wijkverpleging was en er eenmaal meerdere hoogleraren werden aangesteld, volgde het onderzoek en kwam de verpleging ook daardoor veel meer op de maatschappelijke en politieke agenda. Heb je geen onderzoeksgroep, dan gebeurt er weinig op researchgebied.'

\section{Patiënten betrekken}

'We zijn als voetzorgaanbieders een kleine groep, maar de problematiek waar mens en samenleving mee geconfronteerd worden bij te weinig aandacht voor voetzorg, is groot.

\section{Stichting Loop}

Stichting Loop is in 2000 in het leven geroepen om de afgestudeerden van de Academie voor Podologie (ingeschaald op NLQF 6-niveau) te voorzien van een brancheorganisatie met daarbij een kwaliteitsregister.

Stichting Loop maakte een vergelijkbare ontwikkeling door als ProVoet als het gaat om duidelijkheid verschaffen naar verwijzers, patiënten en zorgverzekeraars en inspelen op een veranderende zorgmarkt.

Omdat iedereen zich podoloog kan noemen, werd eerder al onderscheid gemaakt tussen podologen en registerpodologen. Alleen de podologen die zich inschrijven bij stichting Loop en voldoen aan vastgestelde kwaliteitseisen mogen zich registerpodoloog noemen.

In 2017 veranderde de brancheorganisatie ook de benaming van de verschillende profielen en de inrichting daarvan. Aan de ene kant zijn de beroepen geplaatst die niet-verzekerde zorg leveren, te weten de voetkundig adviseur en de voetkundig sportadviseur. Aan de andere kant staan de beroepen die verzekerde zorg leveren, te weten de registerpodoloog en de podoposturaal therapeut. Zie onderstaande tabel.

De opleiding tot registerpodoloog duurt vier jaar. Na het eerste semester heb je de basisopleiding Podologie voltooid en kun je je voetkundig adviseur noemen.

\section{ONDERSCHEID NIET-VERZEKERDE EN VERZEKERDE ZORG}

Voorzorg (niet-verzekerde zorg)

\section{Voetkundig adviseur en}

Voetkundig sportadviseur

\section{Nuldelijnszorg}

\section{Kerntaken:}

- Analyse

- Voorlichting

- Advisering

- Primaire preventie

- Verwijzing

Werkt samen met nulde- en eerstelijnszorg
Paramedische zorg (verzekerde zorg)

Podoposturaal therapeut en registerpodoloog

\section{Eerstelijnszorg}

Kerntaken:

- Onderzoek

- Diagnostiek

- Therapie

- Secundaire preventie

- Verwijzing

Werkt samen met nulde, eerste- en tweedelijnszorg

\section{Geregistreerd bij KABIZ}

De gevolgen van problemen aan de voeten moeten veel meer bekendheid krijgen. Het zou niet verkeerd zijn om daar patiënten bij te betrekken. Zij weten immers als geen ander welke problemen ze ervaren als ze verstoken zijn van voetzorg en wat het betekent als ze wel professionele voetzorg ontvangen.'

In de slipstream van hun verhaal kunnen we volgens Lensink onder de aandacht brengen hoe voetzorgaanbieders grote problemen kunnen voorkomen als je tijdig screent en behandelt.
'Het moet in Nederland vanzelfsprekend zijn dat je naar een voet laat kijken. In Engeland gaat dat veel meer vanzelf.'

\section{Congres}

'Kortom: we moeten ons als aanbieders van voetzorg samen sterk maken om landelijk actie te ondernemen. De kwaliteit van de voetzorg verdient aandacht. Hoe we dat kunnen doen staat onder meer centraal tijdens ons onlinecongres op 8 november.' 